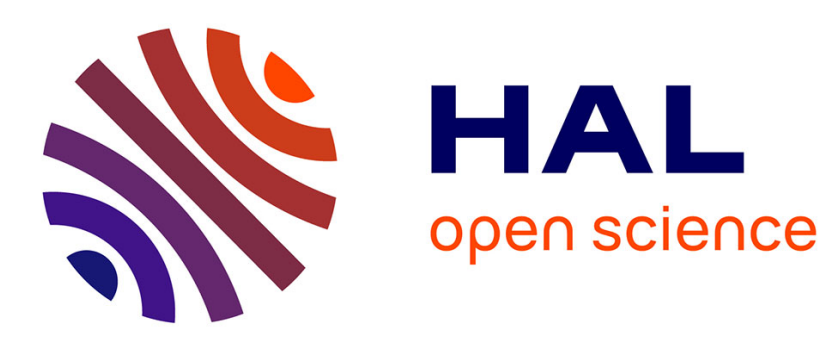

\title{
Remarkable changes of weed species in Spanish cereal fields from 1976 to 2007
}

Cirujeda, Aibar, Zaragoza

\section{To cite this version:}

Cirujeda, Aibar, Zaragoza. Remarkable changes of weed species in Spanish cereal fields from 1976 to 2007. Agronomy for Sustainable Development, 2011, 31 (4), pp.675-688. 10.1007/s13593-011-0030-4 . hal-00930501

\section{HAL Id: hal-00930501 https://hal.science/hal-00930501}

Submitted on 1 Jan 2011

HAL is a multi-disciplinary open access archive for the deposit and dissemination of scientific research documents, whether they are published or not. The documents may come from teaching and research institutions in France or abroad, or from public or private research centers.
L'archive ouverte pluridisciplinaire HAL, est destinée au dépôt et à la diffusion de documents scientifiques de niveau recherche, publiés ou non, émanant des établissements d'enseignement et de recherche français ou étrangers, des laboratoires publics ou privés. 


\title{
Remarkable changes of weed species in Spanish cereal fields from 1976 to 2007
}

\author{
Alicia Cirujeda • Joaquín Aibar • Carlos Zaragoza
}

Accepted: 4 January 2011 / Published online: 18 March 2011

(C) INRA and Springer Science+Business Media B.V. 2011

\begin{abstract}
Management practices, geographical gradients and climatic factors are factors explaining weed species composition and richness in cereal fields from Northern and Central Europe. In the Mediterranean area, the precise factors responsible for weed distribution are less known due to the lack of data and surveys. The existence of weed survey data of year 1976 in the Zaragoza province of the Aragón region, Spain, offered us the opportunity to compare present weed species with weed species growing 30 years ago. No detailed comparison of changes in weed species composition in cereal fields in that period of time has been conducted in the Mediterranean area. Here a survey was conducted in the Aragón region from 2005 to 2007. Weeds were surveyed in 138 winter cereal fields in ten survey areas where winter cereals are the main crops, using the same methodology applied 30 years ago. In the Zaragoza province, 36 fields were chosen in the same municipalities than in the previous survey. Several management, geographic and climatic variables of each field were recorded and related to weed species with multivariate analysis. Diversity index were calculated and related to survey area and altitude. Our results show that out of the 175 species only 26 species were found in more than $10 \%$ of the surveyed fields. The main species were Papaver rhoeas, Lolium rigidum, Avena sterilis and
\end{abstract}

\footnotetext{
A. Cirujeda $(\bowtie) \cdot$ C. Zaragoza

Centro de Investigación y Tecnología Agroalimentaria, Gobierno de Aragón, Unidad de Sanidad Vegetal, Avda. Montañana 930,

50059 Zaragoza, Spain

e-mail: acirujeda@aragon.es

J. Aibar

Escuela Universitaria Politécnica Superior de Huesca,

Ctra. de Zaragoza, Km 67,

22071 Huesca, Spain
}

Convolvulus arvensis found in more than half of the surveyed fields. L. rigidum was related to dryland, while the other species were found overall. Furthermore, we found that management, geographical and climatic factors were significantly related to weed species distribution. In particular altitude, survey areas, irrigation and herbicide use in post-emergence were the most driving factors explaining weed species distribution. Species richness was higher in survey areas with extensive management practices and increased with altitude excepting a very productive area with intensive management practices at high altitude where richness was as low as in the irrigated lowlands. The main differences found between the 1976 and the 2005-2007 surveys were (1) the striking increase of grass weeds, (2) the high decrease of mean weed species number found in each field declining from 9 to 3 and (3) the frequency decrease of many weed species probably caused by agriculture intensification in that period of time. The growing importance of other weed species is probably related to their adaptation to minimum tillage, which is a widespread technique nowadays.

Keywords Biodiversity - Canonical correspondence analysis $\cdot$ Rare weeds $\cdot$ Weed diversity

\section{Introduction}

Patterns of weed species composition in cereal fields are often attributable to a complex number of interacting factors and multivariate analysis has been used in many studies to discuss them. Management practices, geographical gradients and climatic factors have been found to be the most driving factors to explain weed species composition and richness in Northern Europe (Salonen 1993) and in Central 
Europe (Pysek et al. 2005; Lososova et al. 2004; Cimalova and Lososova 2009; Fried et al. 2008). The breadth of the environmental gradients considered is probably an important reason explaining discrepancies of the importance of these factors between studies (Fried et al. 2008). So far, no multivariate analysis of broad-scale gradients as altitude or management practices in cereal fields have been done on weed species composition in Mediterranean areas, but we hypothesize that both factors may be important in the Aragón region due to the broad extent of the altitude gradient and of the diverse management practices found.

Weed species are adapted to crops and to management techniques like soil disturbance by tillage or ploughing. However, intensification in the last decades with chemical fertilization, use of herbicides, sowing high-competitive cereal varieties, using seed-cleaning techniques etc. has reduced species richness (reviewed by Roschewitz et al. 2005). Studies have been conducted to analyse the individual impact of these techniques on weed communities' diversity and fertilization was found to be an important factor affecting weed community composition (Pysek and Leps 1991).

To assess the real scale of these intensification factors, recent surveys have been conducted in many countries to compare weed flora composition with those of previous surveys decades ago. Excepting Andreasen and Stryhn (2008) in Denmark, most of the authors describe an important decline in species number (Albrecht 1995, Germany; Sutcliffe and Kay 2000, United Kingdom; Lososova et al. 2004 and Pysek et al. 2005, Czech Republic and Slovakia). Detailed comparisons in the Mediterranean area are non-existing but Chamorro et al. (2007) in Spain and Speranza et al. (1990) in Italy observed an overall species decline in the last decades based on literature comparisons. We hypothesize that weed species number has also decreased in the most intensive areas of Aragón but may remain high in the extensive areas.

Attention on rare species is paid in many of the published surveys, which besides their intrinsic value, can play a role in agroecosystem functioning. These plants serve as habitat and food for insects, birds and other animals, as well as for soil life. The intense interest shown in some North European countries for rare arable weeds is less in Spain, and the Catalogue of Endangered Species of Flora in Aragón does not include rare weeds (Gobierno de Aragón 2007). As explained by Braun-Blanquet and de Bolós (1957), the semiarid regions of the occidental Mediterranean area are especially rich in weed species and there is a gradual decrease in weed species number towards the north of Europe. Perhaps intensification in agroecosystems has also been lower in Southern Europe than in North European countries so that we hypothesize to find in our survey more rare species than in other North European countries.
The most recent weed survey in cereal fields in the Aragón region was conducted in 1976 describing the flora of the Zaragoza province (Zaragoza and Maillet 1976; Zaragoza-Larios and Maillet 1980). The methodology was very similar to the one used in our study conducted in 2005-2007 allowing the comparison of the weed flora 30 years later in the same surveyed area. This way it was aimed to provide an insight into any changes that may have occurred. Because of lack of data of the rest of Aragón, it is not possible to compare the changes in the other two provinces. However, extending the survey to these regions where a generally more extensive agriculture is common can help determine which factors promote diversity of rare weed species. To our knowledge, this is the first study that establishes a detailed comparison of weed abundance 30 years ago with nowadays in cereal fields located very close to each other in the same municipalities in the Mediterranean region.

The aims of this study were (a) to describe the weed composition in cereal fields of the Aragón region in Spain and its relationship with climatic, geographic and agronomic management factors; (b) to find out which are the frequent and the rare weed species and (c) to compare weed species frequency in the same municipalities of the Zaragoza province 30 years after the survey conducted in 1976.

\section{Material and methods}

\subsection{Field survey}

Aragón is one of the 17 Autonomous Communities of Spain and is located in the north-eastern part of the country. It is comprised of three provinces: Zaragoza, Huesca and Teruel between latitude $42.852^{\circ} \mathrm{N}$ and $39.848^{\circ} \mathrm{N}$ and longitude $2.159^{\circ} \mathrm{W}$ and $0.744^{\circ} \mathrm{E}$. The Aragón region has diverse landscapes and winter cereal is grown from $160 \mathrm{~m}$ altitude in the Ebro Basin to $1,400 \mathrm{~m}$ in the Pyrenees or in the Sistema Ibérico mountains. Agricultural intensification practices such as seed-cleaning techniques, synthetic fertilizers and the development of competitive crops are common throughout, but other techniques such as herbicides and crop rotations differ considerably within these areas. In some highlands of the Teruel and Huesca provinces, agriculture is still quite traditional with low-input management and the soil is left set-aside 1 of 2 years. In contrast, in the irrigated Ebro Basin (Zaragoza province), crop rotations, fertilizers and herbicides are common. To cover the high diversity of landscape and agricultural practices, the survey was organised by choosing different areas where cereal production is important (Fig. 1, Table 1). The number of surveyed winter cereal fields was 62, 21 and 55 in 2005, 2006 and 2007, respectively. In the Zaragoza province, 36 
Fig. 1 Location of the surveyed fields in Aragón (Spain)

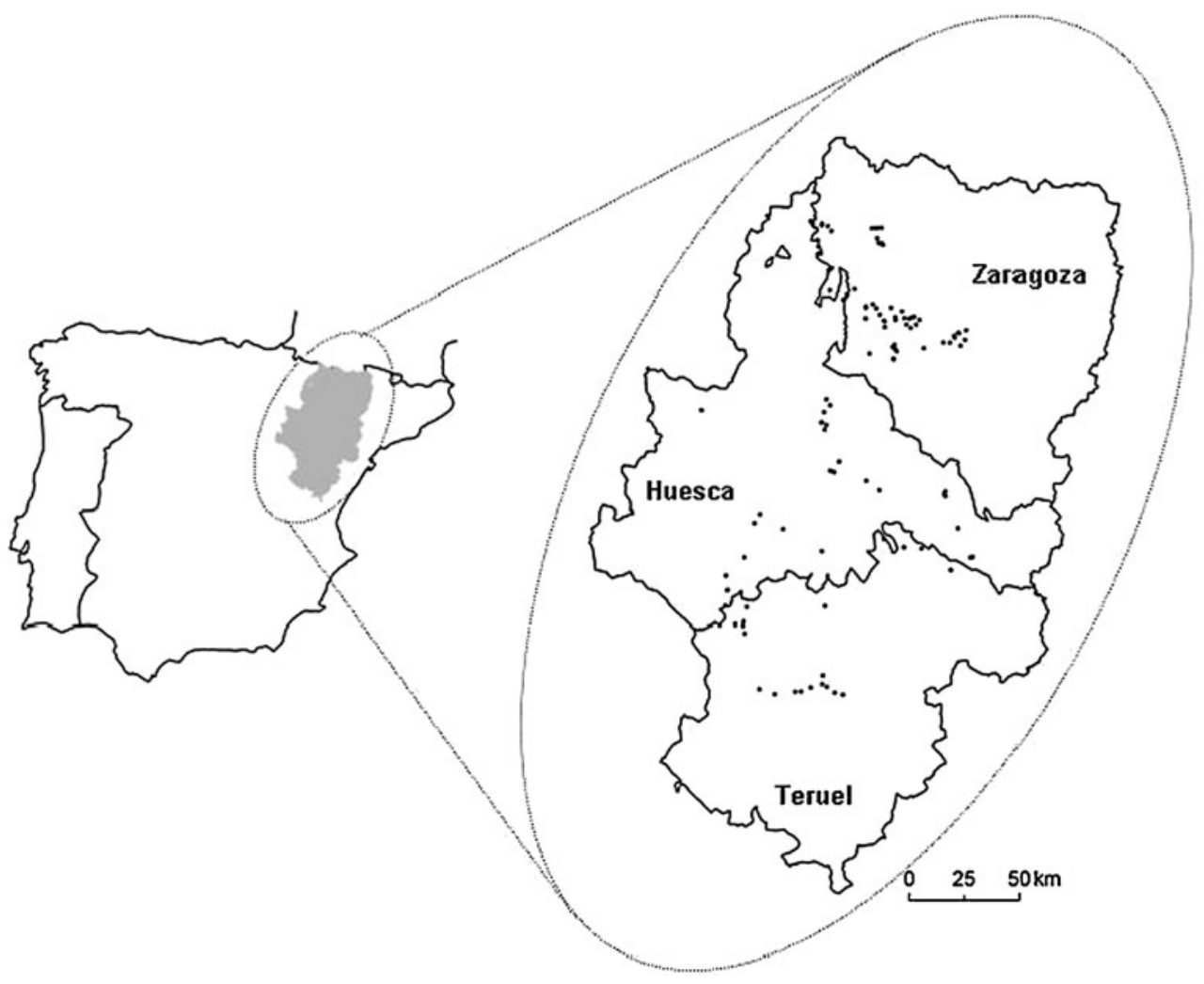

fields were chosen as close as possible to the 21 fields surveyed in 1976 (Zaragoza and Maillet 1976). Despite the amount of surveyed fields in 1976 is not huge, this information is very valuable and difficult to find even more because the person who gathered the data is still active and participated in the 2005-2007 survey.

The survey was done at the heading stage of cereal development in all cases, which occurred between April and June to avoid possible differences in vegetation caused by visiting the fields at different times. The fields were selected randomly in areas with important cereal production avoiding mixed crop areas where cereals are marginal crops following secondary roads and vegetation was described in zigzag transects by three trained persons including the field margin during at least 30 min until no more new species were found, which is a similar methodology as described by Poggio et al. (2004). Approximately 2 ha were surveyed if the whole field could not be covered in that period. One estimation of the observations was given globally and species appearing only in the margins were excluded. This method was preferred to counting weeds in frames, which is very inconvenient at heading stage of the crop, because

Table 1 Some characteristics of the surveyed areas in the Aragón region of Spain

\begin{tabular}{|c|c|c|c|c|c|c|}
\hline Survey area & $\begin{array}{l}\text { Number of } \\
\text { samples }\end{array}$ & $\begin{array}{l}\text { Irrigated } \\
\text { fields }\end{array}$ & $\begin{array}{l}\text { Set-aside is } \\
\text { normal }\end{array}$ & $\begin{array}{l}\text { Use of herbicides and } \\
\text { fertilizers every year }\end{array}$ & Altitude & $\begin{array}{l}\text { Mean altitude of } \\
\text { the surveyed fields }\end{array}$ \\
\hline 1. Hoya Huesca I & 15 & 10 & No & Yes & $377-627$ & 502 \\
\hline 2. Ayerbe area & 13 & 0 & No & Yes & $488-847$ & 667.5 \\
\hline 3. Hoya Huesca II & 14 & 0 & No & Yes & $484-740$ & 612 \\
\hline 4. Jacetania & 20 & 1 & No & Yes & $609-1,068$ & 838.5 \\
\hline 5. Gállego valley & 12 & 12 & No & Yes & $238-284$ & 261 \\
\hline 6. Ebro valley & 12 & 9 & No & Yes & $166-340$ & 253 \\
\hline 7. Bajo Aragón and south Zaragoza & 14 & 5 & Yes & No & $157-531$ & 344 \\
\hline 8. Bajo Teruel & 11 & 1 & Yes & No & $800-1,047$ & 924 \\
\hline 9. Somontano and Graus & 14 & 0 & No & Yes & $350-593$ & 472 \\
\hline 10. Cuencas Mineras and Teruel & 14 & 0 & Yes & No & $790-1,390$ & 1,090 \\
\hline
\end{tabular}


more species are found this way and because weeds occurring in patches as described by Izquierdo et al. (2009) are taken into account more realistically with an overall assessment. Flora Europaea (Tutin et al. 19641980) was used for weed species identification. The abundance of all species found was recorded according to the visual CEB scale which relates plant density with weed soil cover, allowing a better estimation in the lower abundance categories. The CEB scale ranges from 1 to 10 , which corresponds to categories of soil cover percentages of $<1 \%$ (rare plants), $1-7 \%\left(<1\right.$ plant $\left.\mathrm{m}^{-2}\right), 7-15 \%$ $\left(>1\right.$ plant $\left.\mathrm{m}^{-2}\right), 15-30 \%, 30-50 \%, 50-70 \%, 70-85 \%, 85-$ $93 \%$ and $93-100 \%$.

Additional data was recorded during the survey: coordinates and altitude of the field, crop type, visual percentage of crop cover, data on possibility of irrigation of the field and data on evident use of herbicides in late post-emergence. Other parameters for each field were found in laboratory: field size (using the Sigpac database, http:// sigpac.mapa.es/fega/visor/) and the official climatic variables used by the regional Agency of the Aragón Environmental Government (http://portal.aragon.es/portal/page/ portal/MEDIOAMBIENTE/cclimatico/Atlas); climatic division of Aragón for each field following the criteria of Köppen (mean annual and monthly values of temperature and rainfall); the aridity index following the classification system of the United Nations Environmental Programme and the annual hidric balance. The phytoclimatic environment, which is the dominant vegetation community in the area, was given for each field following Villar and Sesé (2000). Table 2 summarizes the recorded explanatory variables.

\subsection{Data analysis}

The Gini-Simpson's diversity index $(1-D)$ was calculated for each field following $(1-D)^{\prime}=1-\sum\left(p_{i}\right)^{2}$ where $p_{i}=\frac{n_{i}}{N_{i}}$. Shannon's eveness index was calculated following $E=H^{\prime}(\ln N)^{-1}$ (Magurran 1988).

Canoco 4.5 for Windows (ter Braak and Smilauer 2002) was used for direct gradient analysis. Weed data set was subjected first to a Detrended Correspondence Analysis from the CANOCO 4.5 package (ter Braak and Smilauer 2002). The length of the gradient bigger than three lead us to reduce the noise of the data set. For this purpose, the seven crop species occurring as weeds (wheat, barley, oats, rye, peas, alfalfa, sunflower) were excluded from the analysis as suggested by Hallgren et al. (1999). Rare species were downweighted with the same aim. In a first canonical correspondence analysis (CCA), nominal variables were coded as series of zero/one dummy variables and scaling was focused on inter-species distance with a biplot scaling. Year was found significant but did not contribute in a practical interpretation of results because different areas were surveyed in different years. Taking into account that the rest of explanatory variables explained significantly weed species composition, this variable was excluded from further analysis following Hallgren et al. (1999).

Gross and net effects of individual explanatory variables on weed species composition were tested using the Monte Carlo permutation tests with 999 permutations in CCA (ter Braak and Smilauer 2002), following the methodology of Lososova et al. (2004). The gross effect of an explanatory variable was tested using separate CCAs with a single explanatory variable. The net effect was tested using partial CCAs, each with a single explanatory variable and using the other variables as covariables. Net effects express the effect of a single variable after partialling out the effects shared with the other explanatory variables. We used the ratio of a particular canonical eigenvalue over the sum of all eigenvalues (total inertia) as a measure of the proportion of variation explained by each factor, respectively (Lososova et al. 2004; Fried et al. 2008).

To satisfy normality and variance homogeneity, the number of weed species and the total abundance needed $\sqrt{ }(x)$ transformation and the diversity and eveness indexes $(x)^{2}$ transformation, following the indications of the BoxCox Transformation (Bowley 1999). Data were submitted to a standard ANOVA using the SAS/STAT procedures PROC GLM (SAS version 8; SAS Institute 1991). Statistical significance between means was tested on the basis of the Student-Neumann-Keuls test at $P<0.05$. Altitude was divided in five groups with a similar number of samples in each group to allow conducting an ANOVA. Mean abundance as a measure of weediness was calculated by taking the median soil cover of each CEB scale value: $0.2 \%, 4 \%, 11 \%, 22.5 \%, 40 \%, 60 \%, 77.5 \%, 89 \%$ and $96.5 \%$ for the values $1,2,3,4,5,6,7,8$ and 9 , respectively.

\subsection{Comparison with the 1976 survey}

In 2005-2007, 36 surveyed fields in the Zaragoza province were chosen in the same municipalities and as closed as possible to the fields sampled in 1976. The fields account for the survey areas 5, 6 and partly for areas 7 and 8. A similar methodology was used in both surveys, and the fields were also visited in the same period of the year.

\section{Results and discussion}

\subsection{General results of the survey}

We found 175 different weed species and seven volunteer crops in 138 fields, and 131 genera belonging to 26 families, which is a similar number of species compared 
Table 2 Recorded explanatory variables

\begin{tabular}{|c|c|c|}
\hline Variable & Method used & Range \\
\hline \multicolumn{3}{|l|}{ Management variables } \\
\hline Crop cover & FO & $40-100 \%$ \\
\hline Crop type & FO & Wheat, durum wheat, barley, oat, rye \\
\hline Irrigation & FO & Irrigation, no irrigation \\
\hline Herbicide use in late post-emergence & FO & Herbicide, no herbicide \\
\hline Field size & AP & $0.3-2$ ha \\
\hline \multicolumn{3}{|l|}{ Geographic variables } \\
\hline Survey area & AP & Area $1,2,3,4,5,6,7,8,9,10$ \\
\hline Altitude & FO & $157-1,390 \mathrm{~m}$ \\
\hline Phytoclimatic environments & $\mathrm{ADD}^{\mathrm{b}}$ & $\begin{array}{l}\text { Quercus faginea, Quercus ilex, Quercus coccinea, } \\
\text { Lygeum spartium }\end{array}$ \\
\hline \multicolumn{3}{|l|}{ Climatic variables } \\
\hline Year & FO & $2005,2006,2007$ \\
\hline Annual hidric balance & $\mathrm{ADD}^{\mathrm{a}}$ & $\begin{array}{l}\text { Less than }-800 \mathrm{~mm} ;-800 \text { to }-700 \mathrm{~mm} ;-700 \\
\text { to }-500 \mathrm{~mm} ;-500 \text { to }-400 \mathrm{~mm} ;-400 \text { to }-200 \mathrm{~mm}\end{array}$ \\
\hline Climatic division of Aragón & $\mathrm{ADD}^{\mathrm{a}}$ & $\begin{array}{l}\text { Dry steppe, continental Mediterranean, transition } \\
\text { mediterranean-oceanic, warm submediterranean } \\
\text { continental, cold submediterranean continental }\end{array}$ \\
\hline Aridity index (UNEP) & $\mathrm{ADD}^{\mathrm{a}}$ & $\begin{array}{l}\text { Subhumid-moist (index } 0.70-1 \text { ), subhumid-dry } \\
\quad \text { (index } 0.50-0.70 \text { ), semiarid (index }<0.30-0.50 \text { ) }\end{array}$ \\
\hline
\end{tabular}

$U N E P$ United Nations Environmental Programme, $F O$ field observation, $A P$ aerial photograph, $A D D$ analysis of digital databas

${ }^{\mathrm{a}}$ http://portal.aragob.es

${ }^{\mathrm{b}}$ Villar and Sesé (2000)

to other surveys done in the Mediterranean area on a comparable number of cereal fields: Portugal, 278 species in 155 fields (Sá et al. 1992); Greece, 103 species in 86 fields (Damanakis 1983) and Morocco, 315 species in 218 fields (Taleb and Maillet 1994a). As expected from a phytosociological point of view (Braun-Blanquet and de Bolós 1957), these figures are higher than found in Northern Europe visiting a similar number of fields: South Central England, 46 species found in 100 fields (Sutcliffe and Kay 2000) and Denmark, 126 species in 165 fields (Salonen et al. 2001). Even studying many more fields, far fewer species were found in surveys done in Northern Europe: England, 87 species in 1,021 fields (Chancellor and Froud-Williams 1984) and Finland, 160 species in 690 fields (Salonen et al. 2001).

Only 26 species were found in more than $10 \%$ of the fields, and these were considered frequent weeds. Only four species (Papaver rhoeas, Lolium rigidum, Avena sterilis and Convolvulus arvensis) were found in more than half of the surveyed fields (Table 3 ). P. rhoeas, L. rigidum and $A$. sterilis were the most frequent and also the most abundant weed species (Table 3). Considering these parameters, $L$. rigidum was the most abundant weed but was concentrated in dryland areas found in $71 \%$ of the rainfed fields and only in $26 \%$ of the irrigated fields. Thus, P. rhoeas and A. sterilis likely can be considered the worst weeds of cereals in Aragón as they can be difficult to control and moreover may exhibit herbicide resistance (Centro de Protección Vegetal 2005). The next species of importance were $C$. arvensis, Fumaria spp. and Polygonum aviculare, which are less competitive due to their later emergence at the end of winter or early spring.

\subsection{Relationship between weed species composition and environmental factors}

The influence of the environmental variables on weed species composition overall was detected using CCA including only significant environmental variables one by one, from most significant to less significant, following the Monte Carlo permutation test. These significant variables were altitude, aridity index, irrigation, survey areas, herbicide use, annual hidric balance and crop type (Fig. 2). The first axis explained $16.2 \%$ of the variation and was mostly correlated with survey areas, altitude and irrigation. The second axis explained $11.3 \%$ of the total variation and was also mostly correlated with survey areas, altitude and with the crop type. Thus, altitude and survey areas were related to both axis. This fact and the relatively high eigenvalues of the third and fourth ordination axes 
Table 3 Species with frequency higher than $10 \%$ and mean abundance values following the CEB scale

\begin{tabular}{|c|c|c|c|c|}
\hline Species & Abbreviation & Frequency $(\%)$ & $\begin{array}{l}\text { Mean abundance when present } \\
\text { (\% soil cover) }\end{array}$ & $\begin{array}{l}\text { Mean total abundance } \\
\text { (\% soil cover) }\end{array}$ \\
\hline Papaver rhoeas & PAPRH & $69(1)$ & $3.1(6)$ & $2.2(2)$ \\
\hline Lolium rigidum & LOLRI & $59(2)$ & $6.5(2)$ & $3.8(1)$ \\
\hline Avena sterilis & AVEST & $55(3)$ & $3.7(4)$ & $2.0(3)$ \\
\hline Convolvulus arvensis & CONAR & $53(4)$ & $0.8(12)$ & $0.4(8)$ \\
\hline Fumaria spp. & FUMSS & $34(5)$ & $1.2(10)$ & $0.2(10)$ \\
\hline Polygonum aviculare & POLAV & $32(6)$ & $0.8(12)$ & $0.3(9)$ \\
\hline Galium spp. & GALSS & $31(7)$ & $1.6(9)$ & $0.2(10)$ \\
\hline Cirsium arvense & CIRAR & $28(8)$ & $0.5(14)$ & $0.1(11)$ \\
\hline Chondrilla juncea & CHOJU & $22(9)$ & $2.4(7)$ & $0.5(7)$ \\
\hline Buglossoides arvense & LITAR & $22(9)$ & $0.2(17)$ & $0.04(13)$ \\
\hline Rumex spp. & RUMSS & $21(10)$ & $1.2(10)$ & $0.1(11)$ \\
\hline Lactuca serriola & LACSE & $21(10)$ & $0.6(13)$ & $0.1(11)$ \\
\hline Euphorbia serrata & EPHSR & $20(11)$ & $0.8(12)$ & $0.1(11)$ \\
\hline Vicia $\mathrm{sp}$ & VICSS & $20(11)$ & $0.2(17)$ & $1.0(6)$ \\
\hline Fallopia convolvulus & POLCO & $20(11)$ & $0.3(16)$ & $1.6(4)$ \\
\hline Anacyclus clavatus & ANYCL & $20(11)$ & $2.0(8)$ & $0.4(8)$ \\
\hline Medicago sativa & MEDSA & $18(12)$ & $1.1(11)$ & $0.2(10)$ \\
\hline Hypecoum procumbens & HCYPR & $17(13)$ & $7.6(1)$ & $1.3(5)$ \\
\hline Rapistrum rugosum & RASRU & $17(13)$ & $0.2(17)$ & $0.03(14)$ \\
\hline Bromus spp. & BROSS & $17(13)$ & $0.4(15)$ & $0.1(11)$ \\
\hline Diplotaxis erucoides & DIPER & $14(14)$ & $0.8(12)$ & $0.1(11)$ \\
\hline Avena fatua & AVEFA & $14(14)$ & $3.1(6)$ & $0.4(8)$ \\
\hline Descurania sofia & DESSO & $12(15)$ & $3.8(3)$ & $0.4(8)$ \\
\hline Herniaria hirsuta & HEQHI & $12(15)$ & $0.4(15)$ & $0.1(11)$ \\
\hline Capsella bursa-pastoris & CAPBP & $12(15)$ & $3.2(5)$ & $0.4(8)$ \\
\hline Malva sylvestris & MALSI & $11(16)$ & $0.5(14)$ & $0.05(12)$ \\
\hline
\end{tabular}

In parentheses, rank of the species

( $10.1 \%$ and $8.2 \%$ respectively) indicated the complex nature of weed communities, which was difficult to explain with the chosen environmental variables as also observed by Salonen (1993).

Most of the species with highest fit to the two axes were indeed strongly related to high altitude (Fig. 2): Cerastium perfoliatum L., Delphinium consolida L., Neslia paniculata (L.) Desv., Papaver argemone L., Androsace maxima L., Silene conoidea L. and Vaccaria pyramidata Medik.. These are rare species found mainly in the highlands of Teruel in survey areas 10 and 8 at extensive management systems without irrigation. In this way, altitude was thus related to survey areas.

The importance of irrigation in our analysis is not surprising because weeds growing in irrigated areas and those growing in rainfed conditions form part from different orders in the phytosociological classification (Rivas-Martínez et al. 2002). Also Zaragoza-Larios and Maillet (1980) found irrigation to be the main factor explaining weed species distribution and to a lower extent soil type and altitude. Species mostly related to irrigation, following the weighted averages, were Xanthium strumarium L., Phragmites australis (Cav.) Trin. ex Steud., Picris echioides L. and Poa annua L.. These weeds are typical in lucerne and maize crops and appear in irrigated cereal fields when farmers rotate with these crops. In the CCA, these species were also near to the centroids of the moist aridity index (of regions without irrigation) and to the most positive hidric balance -200 to $-400 \mathrm{~mm}$ (again of regions without irrigation), which shows the relationship between these indexes (Fig. 2).

Species especially related to non-irrigated fields were Glaucium corniculatum (L.) J.H. Rudolph, Malcolmia africana (L.) W.T. Aiton, Silybum marianum (L.) Gaertn., Euphorbia serrata L., Reseda phyteuma L. and Herniaria hirsuta L. The troublesome species, P. rhoeas and A. sterilis were independent of irrigation (Fig. 2) whereas L. rigidum was more related to non-irrigated fields. This weed was 


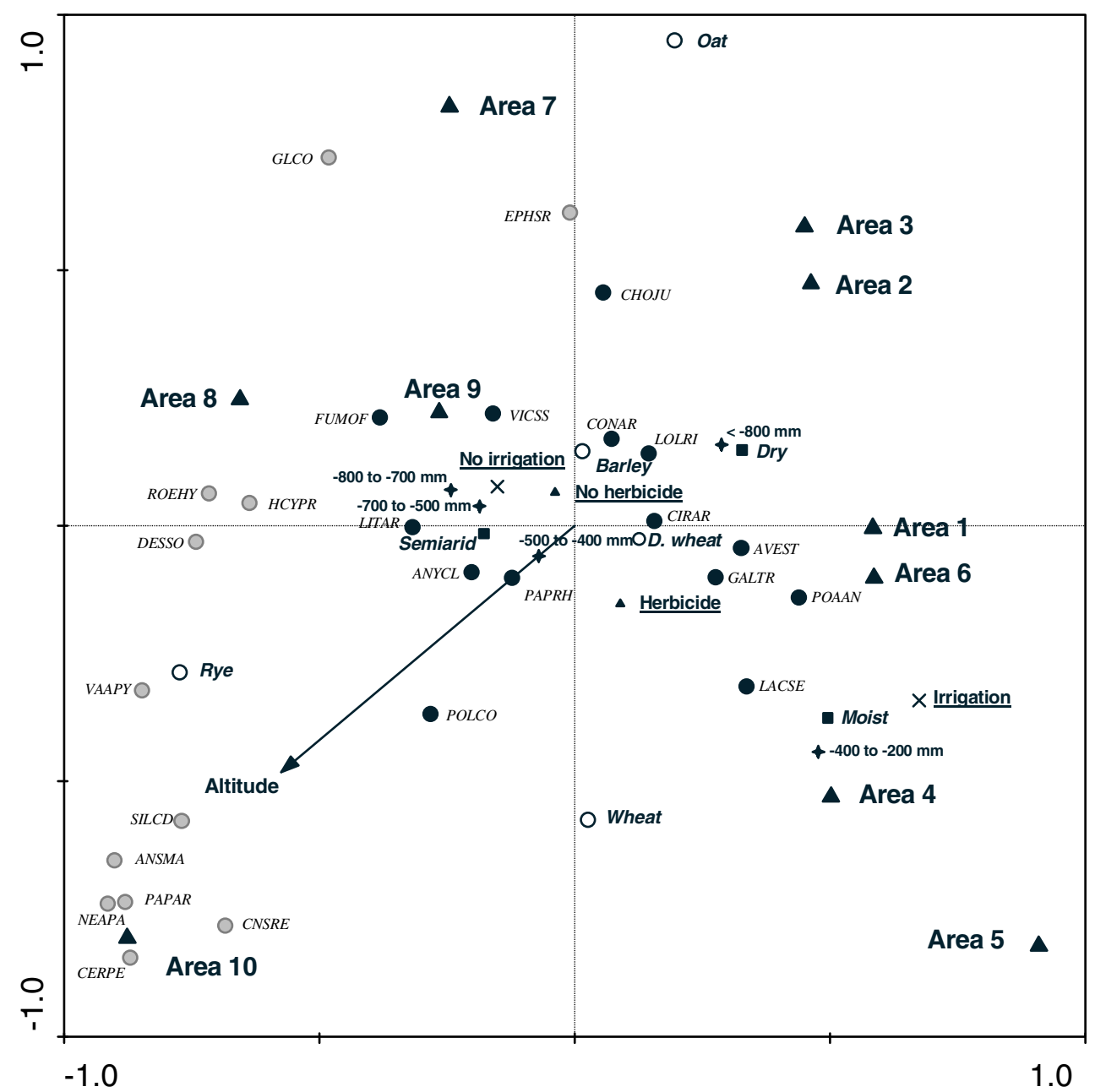

Fig. 2 Canonical correspondence analysis (CCA) ordination of the 15 most frequent weed species (black circles) and of the 12 species with highest fit (grey circles). HCYPR and EPHSR are included in both categories. Variables were added stepwise with a Monte Carlo permutation test, and only significant variables were taken into account. The first two axes explain $27.5 \%$ of the species-environment relations. The codes of the environmental variables are explained in Table 2. ANSMA Androsace maxima L., ANYCL Anacyclus clavatus, AVEST Avena sterilis, CERPE Cerastium perfoliatum L., CHOJU Chondrilla juncea, CIRAR Cirsium arvense, CONAR Convolvulus

found in $71 \%$ of the rainfed fields and only in $26 \%$ of the irrigated fields. All three species were quite independent of other environmental variables, located near to the origin of the ordination diagram, thus found in all the areas and crops similarly (Fig. 2). Taleb and Maillet (1994b) also found P. rhoeas, C. arvensis and Fumaria parviflora to be indifferent to the analysed edaphic and climatic parameters, demonstrating a high adaptation capacity. In the Mediterranean region, $P$. rhoeas is known to grow both in low intensification areas (Taleb and Maillet 1994b) and also in areas with herbicide use (Tanji 2000).

Following the weighted averages species mostly related to herbicide use in last post-emergence, which is normally arvensis, CNSRE Delphinium consolida L., DESSO Descurainia sofia, EPHSR Euphorbia serrata, FUMOF Fumaria officinalis, GALTR Galium tricornutum, GUCCO Glaucium corniculatum (L.) Rudolph/Curt., HCYPR Hypecoum procumbens, LACSE Lactuca serriola, LITAR Buglossoides arvensis, LOLRI Lolium rigidum, MALSI Malva sylvestris, NEAPA Neslia paniculata (L.) Desv., PAPAR Papaver argemone L., PAPRH Papaver rhoeas, POAAN Poa annua L., POLCO Fallopia convolvulus, ROEHY Roemeria hybrida (L.) DC., SILCD Silene conoidea L., VAPY Vaccaria pyramidata Medik., VICSS Vicia spp.

used for broad-leaved weed control, were several nonfrequent grass weeds and late emerging broad-leaved species as Heliotropium europaeum L. and P. echioides L., which probably emerged after treatment.

All environmental variables had a significant gross effect on species composition and most of the variation was explained by survey area (Table 4). Together, these variables explained $48 \%$ of the total variation. However, according to permutation tests, the net effects of only survey areas, irrigation, herbicide use and altitude were significantly linked to species composition (Table 4). The other environmental variables were not significant, showing an important correlation with the other variables. 
Table 4 Percentage variation in species data attributed to the effects of explanatory variables calculated by partial Canonical Correspondence Analysis (CCA) for net effects and CCA with a single variable for gross effects

\begin{tabular}{lccccc}
\hline Factors & \multicolumn{2}{l}{ Gross effects } & & \multicolumn{2}{l}{ Net effects } \\
\cline { 2 - 3 } \cline { 6 - 7 } & $\%$ & & & $\%$ & $P$ \\
\hline Survey area & 14.58 & $* *$ & & 7.28 & $* *$ \\
Climatic division & 7.40 & $* *$ & & 3.05 & $\mathrm{~ns}$ \\
Rainfall & 5.76 & $* *$ & & 3.01 & $\mathrm{~ns}$ \\
Phytoclimatic environment & 4.41 & $* *$ & & 2.06 & $\mathrm{~ns}$ \\
Crop & 3.77 & $* *$ & & 2.70 & $\mathrm{~ns}$ \\
Aridity index & 3.29 & $* *$ & & 1.47 & $\mathrm{~ns}$ \\
Altitude & 2.97 & $* *$ & & 0.98 & $*$ \\
Irrigation & 2.48 & $* *$ & & 1.33 & $* *$ \\
Crop cover & 1.07 & $*$ & & 0.71 & $\mathrm{~ns}$ \\
Herbicides & 0.96 & $*$ & & 0.91 & $* *$ \\
Field size & 0.94 & $*$ & & 0.73 & $\mathrm{~ns}$ \\
\hline
\end{tabular}

The amount of variation explained by the net effects of particular variables, as detected by partial CCAs (Table 4) was also highest for survey areas. In our case, this variable includes the effect of geographic, climatic and factors related to management practices (Table 4) explaining the lack of significance of the net effect of several environmental factors of all three kinds. However, the remaining significant variables considering their net effect are both climatic and related to management and had a similar influence on weed species composition being correlated within each other, as also found by Pysek et al. (2005).

There are certain discrepancies between the importances of climatic, geographic and management factors on weed species composition in studies conducted in other parts of Europe. While Pysek et al. (2005), Fried et al. (2008) and Cimalova and Lososova (2009) found certain management practices to be more relevant than the climatic influence when the study area was relatively homogeneous, Lososova et al. (2004) observed a pronounced influence of climate in a more heterogeneous area. The range of the analysed variables explains these differences. In our case, the broad altitude gradient (157$1,390 \mathrm{~m}$ ) is similar to the one of the survey area of Lososova et al. (2004; 97-1,100 m) and altitude had an important influence in weed species composition also in our study.

On the other hand, also the range of possibilities in the management practices in our study was very wide so that irrigation and herbicide use were also significant in our analysis. Thus, the pattern of weed species distribution in the Aragón region is complex and driven by a number of mutually correlated and interacting climatic, geographic and management factors as also found by Pysek et al. (2005) in Central Europe.

\subsection{Species richness and diversity}

Weed species richness, weediness and Gini-Simpson's (1 $D$ ) diversity index were highest for survey area 10 , where extensive agronomic practices are common located in the highlands of the Teruel province (Table 5). In the irrigated areas 5 and 6, richness, weediness and Gini-Simpson's (1 $D)$ diversity index were the lowest. Crop rotation and intensive herbicide use are probably responsible for this situation. Dominating weed species in those areas were the cosmopolitans P. rhoeas, A. sterilis and, to a lower extent, L. rigidum. However, Shannon's $E^{\prime}$ eveness index was not significantly different for any of the tested areas. Generally, species richness, weediness and Gini-Simpson's $(1-D)$ diversity index increased with altitude as found in Central Europe and France (Lososova et al. 2004, Pysek et al. 2005, Fried et al. 2008). In the case of the Aragón region, human activity and intensification degree decreases with altitude, which probably explains species richness increase with altitude (Table 5). However, there was an interruption of this gradient at the $631-870 \mathrm{~m}$ stripe, which includes mainly fields form survey areas 3 and 4, most of them located in a wide valley in the pre-Pyrenees where yield is high despite of the altitude. Management practices are intensive and, as a consequence, species richness, weediness and diversity were low and similar to the values of the lowland areas.

Generally, highest weediness was found in the most extensive area of Teruel (area 10) but also highest diversity (Table 5). It needs to be highlighted that the most serious weed control problem occurring in that area could be due to Descurainia sophia or Hypecoum procumbens which can appear at high density but which are not dangerous weeds and easily controlled with herbicides. No herbicide resistance is known in that area (Heap 2010) and high infestations of the high-competitive weeds $A$. sterilis $\mathrm{L}$. or L. rigidum Gaud. are very rare. Indeed, in area $10, L$. rigidum was found in $69 \%$ of the surveyed fields but at low mean abundance $(0.6 \%$ cover $)$ compared to $33 \%$ and $17 \%$ occurrence in areas 5 and 6 with a higher mean abundance ( $6.7 \%$ and $2.1 \%$ cover, respectively).

\subsection{Rare weed species}

One hundred forty-nine species, accounting for $85.3 \%$ of the total weed species were found at less than $10 \%$ of the fields demonstrating that many weed species should be considered as rare species in the Aragón cereal fields. Forty-five of them are characteristic species of the class Stellarietea mediae Tüxen, Lohmeyer \& Preisling ex von Rochow (1951) and of their orders and alliances (Rivas-Martínez et al. 2002).

A complete list of all species found is available as supplementary information. Romero et al. (2008) compared 
Table 5 Richness (number of species per field), weediness (total abundance), diversity (Gini-Simpson's diversity index $(1-D))$ and eveness (Shannon's $E$ index) of each area.

Different letters within each parameter refer to statistical differences following Student-

Neumann-Keuls test at $P<0.05$. Number of species and total abundance was $\sqrt{ }(x)$ transformed, eveness was $(x)^{2}$ transformed. Values in parentheses indicate the transformed means corresponding to each of the back-transformed values

${ }^{a}$ Details on the survey areas are explained in Table 1

\begin{tabular}{lllll}
\hline Survey area $^{\mathrm{a}}$ & Richness & Weediness & Diversity & Eveness \\
\hline 1 & $2.84(8.1) \mathrm{b}$ & $3.28(10.8) \mathrm{bc}$ & $0.64 \mathrm{~b}$ & $0.66(0.81) \mathrm{a}$ \\
2 & $3.02(9.1) \mathrm{b}$ & $3.27(10.7) \mathrm{bc}$ & $0.73 \mathrm{ab}$ & $0.85(0.92) \mathrm{a}$ \\
3 & $2.91(8.5) \mathrm{b}$ & $3.06(9.4) \mathrm{bc}$ & $0.69 \mathrm{ab}$ & $0.73(0.85) \mathrm{a}$ \\
4 & $2.99(8.9) \mathrm{b}$ & $3.25(10.6) \mathrm{bc}$ & $0.69 \mathrm{ab}$ & $0.82(0.91) \mathrm{a}$ \\
5 & $2.77(7.7) \mathrm{b}$ & $2.96(8.7) \mathrm{c}$ & $0.71 \mathrm{ab}$ & $0.85(0.92) \mathrm{a}$ \\
6 & $2.83(8.0) \mathrm{b}$ & $3.12(9.7) \mathrm{bc}$ & $0.68 \mathrm{~b}$ & $0.79(0.89) \mathrm{a}$ \\
7 & $3.44(11.8) \mathrm{b}$ & $4.04(16.3) \mathrm{b}$ & $0.79 \mathrm{ab}$ & $0.73(0.85) \mathrm{a}$ \\
8 & $3.71(13.8) \mathrm{b}$ & $4.20(17.6) \mathrm{b}$ & $0.79 \mathrm{ab}$ & $0.77(0.88) \mathrm{a}$ \\
9 & $3.70(13.7) \mathrm{b}$ & $4.05(16.4) \mathrm{b}$ & $0.82 \mathrm{ab}$ & $0.85(0.92) \mathrm{a}$ \\
10 & $4.66(21.7) \mathrm{a}$ & $5.14(26.4) \mathrm{a}$ & $0.87 \mathrm{a}$ & $0.83(0.91) \mathrm{a}$ \\
Altitude & & & & \\
$157-283 \mathrm{~m}$ & $2.87(8.2) \mathrm{b}$ & $3.26(10.6) \mathrm{b}$ & $0.69 \mathrm{~b}$ & $0.77(0.87) \mathrm{a}$ \\
$284-488 \mathrm{~m}$ & $3.17(10.0) \mathrm{b}$ & $3.55(12.6) \mathrm{b}$ & $0.71 \mathrm{ab}$ & $0.76(0.87) \mathrm{a}$ \\
$489-630 \mathrm{~m}$ & $3.47(12.0) \mathrm{ab}$ & $3.80(14.4) \mathrm{ab}$ & $0.78 \mathrm{ab}$ & $0.83(0.91) \mathrm{a}$ \\
$631-870 \mathrm{~m}$ & $2.91(8.5) \mathrm{b}$ & $3.26(10.6) \mathrm{b}$ & $0.67 \mathrm{~b}$ & $0.78(0.88) \mathrm{a}$ \\
$871-1,390 \mathrm{~m}$ & $3.91(15.3) \mathrm{a}$ & $4.33(18.7) \mathrm{a}$ & $0.81 \mathrm{a}$ & $0.80(0.90) \mathrm{a}$ \\
\hline
\end{tabular}

species occurring in conventional and in organically managed farms in the nearby region of Catalonia, thus comparing a package of agronomic management practices. They found $H$. procumbens and Roemeria hybrida (L.) DC. Only in organic farms and Papaver hybridum L. and Scandix pecten-veneris L. more frequently in organic fields. In our case, $H$. procumbens and $R$. hybrida were mainly found in the low input dryland areas 7,8 or $10(78 \%$ and $92 \%$ of the scores, respectively). P. hybridum was also more frequent in these areas (50\% of the scores) but $S$. pecten-veneris (a very rare species found in only $3 \%$ of the surveyed fields) was found in dryland but in quite intensive areas. The similarity in these results suggests that the extensive management practices adopted by organic farmers may have a similar influence on weed composition than the extensive practices of the farmers in Teruel.

3.5 Comparison with the 1976 survey on fields in the same municipalities of Zaragoza

Due to the small available sampling size (21 fields in 1976), only the most striking results can be discussed. The biggest change observed between the two surveys was the importance of grass weeds at present, especially L. rigidum and Avena spp. In 1976, these species were found at such a low frequency and abundance that the authors considered that their increase could still be avoided (Zaragoza and Maillet 1976). The shift from broad-leaved to grass weeds has been observed overall in Spain since the adoption of auxin-like herbicides so that these grass weed species were considered main weeds in most of the cereal areas of Spain already in 1984 (García-Baudin 1984).
Another important aspect is that weed species number in the fields decreased in these years from a mean of nine species in 1976 to only three species in 2005-2007. As a consequence, most weed species were found less times: 22 species were found in more than one third of the fields while in 2005-2007 only four species exceeded this figure, i.e. C. arvensis (58\%), P. rhoeas (53\%), A. sterilis $(39 \%)$ and $P$. aviculare (39\%). As an exception, $C$. arvensis frequency increased in these 30 years from $33 \%$ to $58 \%$, probably due to the minimum tillage practices, which are widespread nowadays. Probably intensive management practices in the Zaragoza area are responsible for the disappearance of most of these species. High susceptibility to herbicides and a negative response to increased nitrogen rates as documented for $P$. hybridum and $P$. argemone by Wilson et al. (1990) are some of the most probable causes for frequency decrease. Similar decreases were reported in England comparing weed flora in the 1960s with year 1997 (Sutcliffe and Kay 2000).

Despite studying a greater survey area and visiting more fields than in 1976, eight species were not found in 20052007 in Aragón overall. Two of them were not frequent in 1976 either (present in only 5\% of the fields: Datura sp. and Festuca pratensis Huds.) but Allium spp., Ammi majus L., Lotus corniculatus L., Plantago coronopus L., Spergula arvensis L. and Urtica urens L. were found in 10\% or more of the fields. 21 more species were not found in the Zaragoza province any more but in the more extensive areas of Teruel, considered a reservoir of rare weed species, or in Huesca (Table 6). Weed species, whose frequency has declined most reaching values below $10 \%$ in the province of Zaragoza in 2005-2007 are Daucus carota L., S. pecten- 
Table 6 Frequency (\%) of weed species found in the 1976 survey (Zaragoza and Maillet 1976) but not in the 2005-2007 survey and vice-versa; next, species that show an important decline reaching a

Species

1976 Zaragoza province frequency lower than $10 \%$ were considered rare species and last, species that were rare in 1976 and have increased in frequency in 2005-2007

\begin{tabular}{|c|c|c|c|}
\hline Agropyron repens & 5 & 0 & 1 \\
\hline Anthemis arvensis & 5 & 0 & 1 \\
\hline Centaurea cyanus & 5 & 0 & 1 \\
\hline Thlaspi arvense & 5 & 0 & 1 \\
\hline Biscutella auriculata & 5 & 0 & 5 \\
\hline Cerastium glomeratum & 5 & 0 & 6 \\
\hline Matricaria chamomila & 5 & 0 & 9 \\
\hline Setaria spp. & 10 & 0 & 1 \\
\hline Taraxacum officinalis & 10 & 0 & 1 \\
\hline Linaria spp. & 10 & 0 & 1 \\
\hline Conringia orientalis & 10 & 0 & 2 \\
\hline Neslia paniculata & 10 & 0 & 4 \\
\hline Androsace maxima & 10 & 0 & 6 \\
\hline Trifolium spp. & 14 & 0 & 2 \\
\hline Chenopodium vulvaria & 14 & 0 & 2 \\
\hline Galium tricornutum & 14 & 0 & 15 \\
\hline Papaver argemone & 24 & 0 & 6 \\
\hline Ranunculus arvensis & 29 & 0 & 6 \\
\hline Scandix pecten-veneris & 33 & 0 & 3 \\
\hline Veronica agrestis & 33 & 0 & 5 \\
\hline Daucus carota & 38 & 0 & 4 \\
\hline Erucastrum nasturtiifolium & 0 & 3 & 7 \\
\hline Heliotropium europaeum & 0 & 3 & 1 \\
\hline Onopordum nervosum & 0 & 3 & 5 \\
\hline Phalaris minor & 0 & 3 & 1 \\
\hline Silybum marianum & 0 & 3 & 7 \\
\hline Alyssum alyssoides & 0 & 6 & 10 \\
\hline Atriplex patula & 0 & 6 & 1 \\
\hline Calystegia sepium & 0 & 6 & 1 \\
\hline Equisetum arvense & 0 & 6 & 4 \\
\hline Eruca vesicaria & 0 & 6 & 5 \\
\hline Filago spp. & 0 & 6 & 9 \\
\hline Glyzhirriza glabra & 0 & 6 & 1 \\
\hline Herniaria hirsuta & 0 & 6 & 12 \\
\hline Cichorium intybus & 0 & 8 & 4 \\
\hline Malva sylvestris & 0 & 8 & 11 \\
\hline Senecio vulgaris & 0 & 8 & 8 \\
\hline Hordeum murinum & 0 & 11 & 5 \\
\hline Kochia scoparia & 0 & 11 & 4 \\
\hline Xanthium strumarium & 0 & 11 & 3 \\
\hline Sorghum halepense & 0 & 14 & 4 \\
\hline Cirsium spp. & 0 & 14 & 9 \\
\hline Phragmites australis & 0 & 25 & 7 \\
\hline Chondrilla juncea & 0 & 28 & 3 \\
\hline Lepidium draba & 48 & 6 & 48 \\
\hline Galium aparine & 43 & 3 & 6 \\
\hline Veronica hederifolia & 38 & 6 & 10 \\
\hline
\end{tabular}


Table 6 (continued)

\begin{tabular}{llll}
\hline Species & 1976 Zaragoza province & 2005-2007 Zaragoza province & 2005-2007 Whole Aragón \\
\hline Capsella bursa-pastoris & 33 & 6 & 12 \\
Papaver hybridum & 33 & 3 & 9 \\
Roemeria hybrida & 29 & 8 & 9 \\
Polygonum convolvulus & 24 & 3 & 20 \\
Rumex spp. & 10 & 31 & 21 \\
Lactuca serriola & 10 & 28 & 21 \\
Euphorbia serrata & 10 & 25 & 20 \\
Silene inflata & 5 & 14 & 9 \\
\hline
\end{tabular}

Sampled fields: 21 in 1976, 36 in the Zaragoza province in 2005-2007 and 138 in whole Aragón in 2005-2007

veneris L., Veronica agrestis L. (Table 6), P. hybridum (from $33 \%$ to $2 \%$ ), R. hybrida (from $29 \%$ to $9 \%$ ) and $H$. procumbens (from $38 \%$ to $11 \%$ ). However, these species were still found in some areas of Teruel.

On the other hand, 22 species were found in 2005-2007 but not in 1976. Most of them were rare in 2005-2007 but Chondrilla juncea L., P. australis (Cav.)Trin., Sorghum halepense (L.) Pers. X. strumarium L., Kochia scoparia (L.) Schrad. and Hordeum murinum L. were surprisingly frequent species in 2005-2007. Several of these species are related to minimum tillage and direct drilling, techniques which are much more frequent nowadays and non-existing before 1980 in Aragón (Sopena 2007): Alyssum alyssoides (L.) L., C. juncea L. (Mas and Verdú 2003), Cichorium intybus L., Cirsium spp., Filago spp., Glycyrrhiza glabra L., H. hirsuta L., H. murinum L., K. scoparia (L.) A.J. Scott, Onopordum nervosum Boiss. and S. marianum (L.) Gaertn. Other species are tolerant to the commonly used herbicide glyphosate in pre-sowing, which was not used in 1976, and who require the addition of special surfactants or other compounds for their control (Monsanto 2010): Equisetum arvense L. and Malva sylvestris L. Another group of species found in 2005-2007 and not in 1976 need high temperatures to germinate and their earlier presence in cereal fields could be due to global warming: Calystegia sepium (L.) R. Br., $H$. europaeum L., Phalaris minor Retz., S. halepense (L.) Pers. and $X$. strumarium L. The presence of the Brassicaceae Eruca vesicaria (L.) Cav. and Erucastrum nasturtiifolium (Poir.) O. E. Schulz is difficult to explain, as well as the presence of Atriplex prostrata Bouchér ex DC., Rumex pulcher L., Senecio vulgaris L. and P. australis.

The most striking results are in agreement with the expected changes in time (Zaragoza, personal communication). Despite that only a relatively small area could be used for comparison (21 fields in 1976), probably the huge intensification of agriculture in that period of time and the fact that very near fields were surveyed both times with the same survey technique allowed to reflect the main changes occurred between 1976 and 2005-2007.

\section{Conclusions}

Only four species are found in more than half of the surveyed cereal fields of the Aragón region showing that there is still a big diversity in weed flora in Aragón. Thus, weed management problems are locally different and need specific advice to be solved.

Changes in agriculture between 1976 and 2005-2007 have had an influence in weed species frequency and abundance. The mean species number in each field has declined drastically showing that current management practices, globally, have a negative influence on weed biodiversity. On the other hand, the increase of other weed species adapted to the current minimum tillage techniques demonstrate the plasticity of plant species and their continuous adaptation to management practices. Higher diversity was found in areas with extensive management practices showing that regulations favouring the adoption of these practices could contribute increasing the presence of characteristic weed species which have declined in more intensive areas.

Acknowledgements This study has been supported by the Project CICYT. AGL2004-04836. We thank María León, Gabriel Pardo and Soledad Nuñez for their assistance in field and laboratory.

\section{Appendix}

Table 7

Table 7 List of weed species found in the survey conducted between 2005 and 2007

\begin{tabular}{ll}
\hline & Species \\
\hline 1 & Adonis aestivalis \\
2 & Agropyron repens \\
3 & Agrostemma githago \\
4 & Alopecurus myosuroides \\
5 & Alyssum alyssoides
\end{tabular}


Table 7 (continued)

\begin{tabular}{|c|c|c|c|}
\hline & Species & & Species \\
\hline 6 & Alyssum sp. & 55 & Descurainia sophia \\
\hline 7 & Amaranthus blitoides & 56 & Diplotaxis erucoides \\
\hline 8 & Anacyclus clavatus & 57 & Draba verna \\
\hline 9 & Anagallis arvense & 58 & Echinochloa sp. \\
\hline 10 & Anchusa azurea & 59 & Echium vulgare \\
\hline 11 & Androsace maxima & 60 & Equisetum arvensis \\
\hline 12 & Anthemis arvensis & 61 & Erodium ciconium \\
\hline 13 & Arrhenatherum bulbosum & 62 & Erodium cicutarium \\
\hline 14 & Atriplex patula & 63 & Eruca vesicaria \\
\hline 15 & Atriplex prostrata & 64 & Erucastrum nasturtiifolium \\
\hline 16 & Avena fatua & 65 & Eryngium campestre \\
\hline 17 & Avena sterilis & 66 & Euphorbia helioscopia \\
\hline 18 & Beta vulgaris var. napus & 67 & Euphorbia serrata \\
\hline 19 & Biscutella auriculata & 68 & Fallopia convolvulus \\
\hline 20 & Brassica napus & 69 & Filago pyramidata \\
\hline 21 & Bromus madritensis & 70 & Filago sp. \\
\hline 22 & Bromus rigidus & 71 & Foeniculum vulgare \\
\hline 23 & Bromus sterilis & 72 & Fumaria officinalis \\
\hline 24 & Bromus tectorum & 73 & Fumaria parviflora \\
\hline 25 & Bromus sp. & 74 & Fumaria sp. \\
\hline 26 & Buglossoides arvensis & 75 & Galium aparine \\
\hline 27 & Calendula arvensis & 76 & Galium parisiense \\
\hline 28 & Calystegia sepium & 77 & Galium tricornutum \\
\hline 29 & Camelina sativa & 78 & Galium sp. \\
\hline 30 & Capsella bursa-pastoris & 79 & Geranium molle \\
\hline 31 & Cardaria draba & 80 & Gladiolus segetum \\
\hline 32 & Caucalis platycarpos & 81 & Glaucium corniculatum \\
\hline 33 & Centaurea aspera & 82 & Glycyrrhiza glabra \\
\hline 34 & Centaurea cyanus & 83 & Heliotropium europaeum \\
\hline 35 & Centaurea melitensis & 84 & Herniaria hirsuta \\
\hline 36 & Centaurea solstitialis & 85 & Hordeum murinun \\
\hline 37 & Cerastium glomeratum & 86 & Hyoscyamus niger \\
\hline 38 & Cerastium perfoliatum & 87 & Hypecoum procumbens \\
\hline 39 & Chenopodium album & 88 & Iberis amara \\
\hline 40 & Chenopodium vulvaria & 89 & Kochia scoparia \\
\hline 41 & Chondrilla juncea & 90 & Lactuca saligna \\
\hline 42 & Cichorium intybus & 91 & Lactuca serriola \\
\hline 43 & Cirsium arvense & 92 & Lamium amplexicaule \\
\hline 44 & Cirsium vulgare & 93 & Lathyrus odoratus \\
\hline 45 & Cirsium sp. & 94 & Linaria hirta \\
\hline 46 & Conryngia orientalis & 95 & Linaria micrantha \\
\hline 47 & Consolida pubescens & 96 & Lolium multiflorum \\
\hline 48 & Convolvulus arvensis & 97 & Lolium rigidum \\
\hline 49 & Conyza sp. & 98 & Malcolmia africana \\
\hline 50 & Coronilla scorpioides & 99 & Malva sylvestris \\
\hline 51 & Crepis vesicaria & 100 & Marrubium vulgare \\
\hline 52 & Cynodon dactylon & 101 & Matricacia chamomila \\
\hline 53 & Cynoglossum creticum & 102 & Medicago lupulina \\
\hline 54 & Daucus carota & 103 & Medicago orbicularis \\
\hline
\end{tabular}

Table 7 (continued)

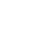

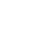


Table 7 (continued)

\begin{tabular}{|c|c|}
\hline & Species \\
\hline 104 & Medicago polimorpha \\
\hline 105 & Medicago sp. \\
\hline 106 & Melilotus officinalis \\
\hline 107 & Muscari comosum \\
\hline 108 & Muscari neglectum \\
\hline 109 & Neslia paniculata \\
\hline 110 & Nigella galica \\
\hline 111 & Ononis sp. \\
\hline 112 & Onopordum nervosum \\
\hline 113 & Papaver argemone \\
\hline 114 & Papaver hybridum \\
\hline 115 & Papaver rhoeas \\
\hline 116 & Phalaris minor \\
\hline 117 & Phragmites australis \\
\hline 118 & Picris echioides \\
\hline 119 & Plantago lanceolata \\
\hline 120 & Plantago mayor \\
\hline 121 & Роа аппиа \\
\hline 122 & Poa trivialis. \\
\hline 123 & Poa sp. \\
\hline 124 & Podospermum laciniatum \\
\hline 125 & Polygonum aviculare \\
\hline 126 & Potentilla reptans \\
\hline 127 & Ranunculus arvense \\
\hline 128 & Raphanus raphanistrum \\
\hline 129 & Rapistum rugosum \\
\hline 130 & Reseda lutea \\
\hline 131 & Reseda phyteuma \\
\hline 132 & Roemeria hybrida \\
\hline 133 & Rumex crispus \\
\hline 134 & Rumex obtusifolius \\
\hline 135 & Rumex pulcher \\
\hline 136 & Rumex sp. \\
\hline 137 & Salsola kali \\
\hline 138 & Salvia sclarea \\
\hline 139 & Sanguisorba minor \\
\hline 140 & Scandix pecten-veneris \\
\hline 141 & Scorzonera hirsuta \\
\hline 142 & Senecio sp. \\
\hline 143 & Senecio vulgaris \\
\hline 144 & Setaria sp. \\
\hline 145 & Silene conica \\
\hline 146 & Silene conoidea \\
\hline 147 & Silene vulgaris \\
\hline 148 & Silybum marianum \\
\hline 149 & Sinapis arvensis \\
\hline 150 & Sisymbrium runcinatum \\
\hline 151 & Sisymbrum irio \\
\hline 152 & Solanum nigrum \\
\hline
\end{tabular}

Table 7 (continued)

\begin{tabular}{|c|c|}
\hline & Species \\
\hline 153 & Sonchus arvense \\
\hline 154 & Sonchus asper \\
\hline 155 & Sonchus oleraceus \\
\hline 156 & Sonchus sp. \\
\hline 157 & Sonchus tenerrimus \\
\hline 158 & Sorghum halepense \\
\hline 159 & Stellaria media \\
\hline 160 & Taraxacum officinalis \\
\hline 161 & Teucrium sp. \\
\hline 162 & Thlaspi arvensis \\
\hline 163 & Torilis nodosa \\
\hline 164 & Trifolium repens \\
\hline 165 & Vaccaria pyramidata \\
\hline 166 & Veronica agrestis \\
\hline 167 & Veronica arvensis \\
\hline 168 & Veronica heredifolia \\
\hline 169 & Veronica persica \\
\hline 170 & Veronica polita \\
\hline 171 & Veronica sp. \\
\hline 172 & Vicia sativa \\
\hline 173 & Viola arvensis \\
\hline 174 & Vulpia unilateralis \\
\hline \multirow[t]{2}{*}{175} & Xanthium strumarium \\
\hline & Volunteer crop plants \\
\hline 1 & Avena sativa \\
\hline 2 & Helianthus аппиа \\
\hline 3 & Hordeum vulgare \\
\hline 4 & Medicago sativa \\
\hline 5 & Pisum sativum \\
\hline 6 & Secale cereale \\
\hline 7 & Triticum aestivum \\
\hline
\end{tabular}

\section{References}

Albrecht H (1995) Changes in the arable weed flora of Germany during the last five decades. Proceedings 9th EWRS (European Weed Research Society) Symposium. Budapest, Hungary, pp 4148

Andreasen C, Stryhn H (2008) Increasing weed flora in Danish arable fields and its importance for biodiversity. Weed Res 48:1-9. doi:10.1111/j.1365-3180.2008.00603.x

Bowley SR (1999) A hitchhiker's guide to statistics in plant biology. Any Old Subject Books, Guelph, Ontario, Canada

Braun-Blanquet J, de Bolós O (1957) Les groupements vegetaux du bassin de l'Ebre. Anales de la Estación Experimental de Aula Dei $5(1-4)$

Centro de Protección Vegetal (2005) Incidencia de plagas y enfermedades en las Comunidades Autónomas en 2004. Aragón Phytoma Esp 167:16-18 
Chamorro L, Romero A, Masalles RM, Sans FX (2007) Cambios en la diversidad de las comunidades arvenses en los cereales de secano en Cataluña. XI Congress of the Spanish Weed Science Society (SEMh). Spain, Albacete, pp 51-55

Chancellor RJ, Froud-Williams RJ (1984) A second survey of cereal weeds in central southern England. Weed Res 24:29-36. doi:10.1111/j.1365-3180.1984.tb00568.x

Cimalova S, Lososova Z (2009) Arable weed vegetation of the noertheastern part of the Czech Republic: effects of environmental factors on species composition. Plant Ecol 203:45-57. doi:10.1007/ s11258-008-9503-1

Damanakis M (1983) Weed species in wheat fields of Greece-1982, 1983 survey. Zizaniology 1:85-90

Fried G, Norton LR, Reboud X (2008) Environmental and management factors determining weed species composition and diversity in France. Agr Ecosyst Environ 128:68-76. doi:10.1016/j.agee.2008.05.003

García-Baudin JM (1984) Espèces adventices graminées dans les céréales d'hiver (blé et orge) espagnoles. Proceedings of the EWRS 3 rd Symposium on Weed Problems in the Mediterranean Area 389-396

Gobierno de Aragón (2007) Catálogo de especies amenazadas en Aragón. Flora. Departamento de Medio Ambiente, Huesca, Spain

Hallgren E, Palmer MW, Milberg P (1999) Data diving with crossvalidation: an investigation of broad-scale gradients in Swedish weed communities. J Ecol 87:1037-1051

Heap I (2010) http://www.weedscience.org/in.asp [accessed on 10 June 2010]

Institute SAS (1991) SAS Systems for linear models. SAS Series in Statistical Applications, SAS Institute, Cary, USA

Izquierdo J, Blanco-Moreno JM, Chamorro L, González-Andújar JL, Sans FX (2009) Spatial distribution of weed diversity within a ceral field. Agron Sustain Dev 29:491-496. doi:10.1051/agro/ 2009009

Lososova Z, Chytry M, Cimalova S, Kropac Z, Otypkova Z, Pysek P, Tichy L (2004) Weed vegetation of arable land in Central Europe: gradients of diversity and species composition. J Veg Sci $15: 415-422$

Magurran AE (1988) Ecological diversity and its measurements. Princetown University, Princetown, USA

Mas MT, Verdú AMC (2003) Tillage system effects on weed communities in a 4-year crop rotation under Mediterranea dryland conditions. Soil Till Res 74:15-24. doi:10.1016/S01671987(03)00079-5

Monsanto (2010) http://www.monsanto.es. [accessed on 10 December 2010]

Poggio SL, Satorre EH, de la Fuente EB (2004) Structure of weed communities occurring in pea and wheat crops in the Rolling Pampa (Argentina). Agr Ecosyst Environ 103:225-235. doi:10.1016/j.agee.2003.09.015

Pysek P, Leps J (1991) Response of a weed community to nitrogenfertilization-a multivariate-analysis. J Veg Sci 2:237-244

Pysek P, Jarosik V, Kropac Z, Chytry M, Wild J, Tichy L (2005) Effects of abiotic factors on species richness and cover in Central European weed communities. Agric Ecosyst Environ 109:1-8. doi:10.1016/j.agee.2005.02.018
Rivas-Martínez S, Díaz TE, Fernández-González F, Izco J, Loidi J, Lousa M, Penas A (2002) Vascular plant communities of Spain and Portugal. Addenda to the Syntaxonomical checklist of 2001. Itinera Geobotanica 15:5-922

Romero A, Chamorro L, Sans FX (2008) Weed diversity in crop edges and inner fields of organic and conventional dryland winter cereal crops in NE Spain. Agr Ecosyst Environ 124:97-104. doi:10.1016/j.agee.2007.08.002

Roschewitz I, Gabriel D, Tscharntke T, Thies C (2005) The effects of landscape complexity on arable weed species diversity in organic and conventional farming. J Appl Ecol 42:873-882. doi:10.1111/ j.1365-2664.2005.01072.x

Sà M, Moreira I, Mira R, Vasconcelos T, Leitao P (1992) Écologie de la végetation du blé dans l'Alto Alentejo (Portugal). Proc. IXème Colloque Int. sur la Biologie des Mauvaises Herbes Dijon, France, 219-228

Salonen J (1993) Weed infestation and factors affecting weed incidence in spring cereal in Finland - a mulitvariate approach. Agric Sci Finl 2:525-536

Salonen J, Hyvönen T, Jalli H (2001) Weeds in spring cereal fields in Finland - a third survey. Agric Food Sci Finland 10:347-364

Sopena P (2007) La siembra directa en Aragón: situación actual. Tierras Castilla León 137:92-95

Speranza M., Govi G., Catizone P. (1990). Crop management and flora of cereals in Italy. Proc. EWRS Symposium, Helsinki, Finland, pp. 163-171

Sutcliffe OL, Kay QON (2000) Changes in the arable flora of central southern England since the 1960s. Biol Conserv 93:1-8

Taleb A, Maillet J (1994a) Mauvaises herbes des céreales de la Chaouia (Maroc). I Aspect floristique Weed Res 34:345-352. doi:10.1111/j.1365-3180.1994.tb02003.x

Taleb A, Maillet J (1994b) Mauvaises herbes des céreales de la Chaouia (Maroc). II Aspect écologique Weed Res 34:353-360. doi:10.1111/j.1365-3180.1994.tb02004.x

Tanji A (2000) Mauvaises herbes du blé et de l'orge dans le périmètre du Tadla. Al Awamia 102:49-57

Ter Braak CJF, Smilauer P (2002) CANOCO reference manual and CanoDraw for Windows User's guide: Software for canonical Community Ordination (version 45). Microcomputer Power, Ithaca, USA

Tutin TG, Heywood VH, Burgues NA, Moore DM, Valentine DH, Walters SM, Webb DA (1964-1980) Flora Europaea. Cambride University Press, Cambridge, United Kingdom

Villar L, Sesé JA (2000) La flora de Aragón en cifras, In: Montserrat P. (Eds). La Flora de Aragón (ed. P Montserrat), 10-11. Colección CAI 100, 80/51, Zaragoza, Spain

Zaragoza C, Maillet J (1976) Flora adventicia en cereales de invierno en la provincia de Zaragoza. Proceedings 1976 VIII Jornadas de Estudio, Asociación Interprofesional para el Desarrollo Agrario (AIDA). Zaragoza, Spain, pp 1-16

Zaragoza-Larios C, Maillet J (1980) Étude de la vegetation adventice de la province de Zaragoza (Espagne). Proceedings 1980 VI Colloque International sur l'Ecologie el la Biologie et la Systematique des Mauvaises Herbes. COLUMA EWRS Montp Fr 1:233-240 